\title{
Scientific rationale of Yagya: a review
}

\author{
Ravi Kant Chaube ${ }^{1 *}$, Vivek Kumar Chaube $^{2}$, Purnendu Saxena ${ }^{3}$, Kuldip Solanki ${ }^{4}$, \\ Rahul Vinay Chandra Tiwari ${ }^{5}$, Heena Tiwari ${ }^{6}$
}

\author{
${ }^{1}$ Department of Radiology, Ultra Care Diagnostic Centre, Civil Lines, Raipur, Chhattisgarh, India \\ ${ }^{2}$ Department of Plastic and reconstructive Surgery, ${ }^{3}$ Department of Orthopedic Surgery, V.Y. Hospital, Raipur, \\ Chhattisgarh, India \\ ${ }^{4}$ Department of Gastroenterology, Solanki Gastro and Endo Centre, Raipur, Chhattisgarh, India \\ ${ }_{5}^{5}$ Department of Oral and Maxillofacial Surgery, CLOVE Dental and OMNI Hospitals, Visakhapatnam, Andhra \\ Pradesh, India \\ ${ }^{6}$ Department of Dental Surgery, CHC Makdi, Kondagaon, Chhattisgarh, India
}

Received: 05 May 2020

Accepted: 03 June 2020

\section{*Correspondence:}

Dr. Ravi Kant Chaube,

E-mail: ravi.chaube@gmail.com

Copyright: (C) the author(s), publisher and licensee Medip Academy. This is an open-access article distributed under the terms of the Creative Commons Attribution Non-Commercial License, which permits unrestricted non-commercial use, distribution, and reproduction in any medium, provided the original work is properly cited.

\begin{abstract}
Yagya is an ancient Hindu Vedic ritual aimed at ablution of the body and surroundings by reinforcing the natural equilibrium in various components of the body and ambient environment. Yagya is directed with selective medicinal preparation of herbs that is forfeited in the holy fire inflamed by specific woods along with the chant of distinct Vedic Hymes (mantras). Medicinal smoke significantly removes human pathogenic microbes. The vaporization and sublimation of ingredients of havan samagri in an inverted pyramid shaped yagya-kunda deliver vast amount of therapeutic and environmental benefits. The chemical transformation (into vapor or gaseous phase/ colloidal forms) of the herbal/ plant medicinal preparations in Hawan lead to release of medicinal phytochemicals; which affect many endogenous chemicals including hormonal axis. These fumes help in purifying the air and have anti-epileptic, antipyretic, anti-fungal, antibacterial effects amongst the numerous other benefits. Regular chanting of hyms helps in purifying the mind. Improvement has been noticed with respect to digestion, hypertension, mental agitation and sleep after chanting the Mantras.
\end{abstract}

Keywords: Agnihotra, Ambient atmosphere, Human body, Hawan, Yagya, Yagna

\section{INTRODUCTION}

From Vedic era, use of yagya (also called Yagna, Hawan or Agnihotra) for health advantage is one of the important functions of Yagya. Yagya was earlier extensively used for preventing and treating various diseases and ailments, and also for refining and maintaining immunity for individuals. Yagya has numerous applications described in Vedic and Ayurvedic literature. For instance, Yagya has been used in solving the difficulties related to environment, in handling natural disasters, for attaining spiritual progress, for preserving ecological balance, for managing social and political balance, and for averting and curing diseases. ${ }^{1}$ The notion of incinerating herbs in the fire to produce medicinal-smoke and taking it through nose, skin and breath and by executing pranayama prevails in the Vedic literature.

\section{COMPOSITION}

The Yagya, which includes the application of medicinal herbs, is recognized as Bheshaj Yagya. Even in contemporary times, application of Bheshaj Yagya is usually seen in Indian culture. ${ }^{2}$ It is an Indian therapeutic procedure of transnasal and pulmonary inhalation and transcutaneous permeation of medicinal-smoke of precise 
herbs produced through sacrifice in specific-fireenvironment for health benefits. ${ }^{3}$ The key reason for this is that Yagya is the process through which one can preserve the natural balance in many components of the environment. ${ }^{4}$

"Agni" means 'fire' and "Hotra" means an 'offering'; Agnihotra means the act of an oblation into the fire. ${ }^{5}$ Agnihotra consists of a base fire generated in a specifically designed vessel fixed on the surface of the level ground. Burning fire of some specified characteristics forms the base fire. To this base fire specific substances like clarified butter (ghee) and herbal materials are added in the form of oblations. ${ }^{4}$

It should be stressed on that the purpose of agnihotra is not to burn the ingredients that are added in the form of oblations, but to vaporize them i.e. to heat them just to the extent that they alter the air quality. Yagya is directed with selective medicinal preparation of herbs that is forfeited in the holy fire of specified woods along with the chant of specific Vedic Hymes (mantras). The chemical reaction and sublimation of selected wood and havan samagri (Table 1, Table 2) in an inverted pyramid shaped yagya-kunda to deliver vast amount of health benefits and therapeutic and environmental purification applications. $^{4}$

Table 1: Woods recommended for the use in hawan.

\begin{tabular}{|lll|}
\hline $\begin{array}{l}\text { Vernacular } \\
\text { name }\end{array}$ & Botanical name & Family \\
\hline Mango & Mangifera indica & Anacardiaceae \\
\hline Sandal-wood & Santalum album & Santalaceae \\
\hline Agar wood & $\begin{array}{l}\text { Aquilana } \\
\text { malaccensis }\end{array}$ & Thymelaeaceae \\
\hline Tagar wood & $\begin{array}{l}\text { Valeriana } \\
\text { wallchii }\end{array}$ & Valerianaceae \\
\hline Deodar (cedar) & Cedrys libani & Pinaceae \\
\hline Dhak or Palash & Butea frondosa & $\begin{array}{l}\text { Fabaceae or } \\
\text { Leguminosae }\end{array}$ \\
\hline Bilva & Aegle marmelos & Rutaceae \\
\hline Pipal & Ficus religiosa & Moraceae \\
\hline $\begin{array}{l}\text { Bargad } \\
\text { (Banyan) }\end{array}$ & Ficus bengalensis & Moraceae \\
\hline Shami & Proposis spicigera & $\begin{array}{l}\text { Fabaceae or } \\
\text { Leguminosae }\end{array}$ \\
\hline Gular (wild fig) & Ficus glomerata & Moraceae \\
\hline Ber & Zizphus jujube & Rhamnaceae \\
\hline
\end{tabular}

It was detected that the ability of the smoke to purify the air was maintained up to 24 hours in the closed room. Absence of many pathogenic bacteria even after 30 days was suggestive of the bactericidal potential of the medicinal smoke treatment. ${ }^{6}$ In another study, Biofumigation was supported by sweltering the mixture of selected plant with fumigation catalyst with ghee and cow dung cakes.
Various holy sticks (dhoop) made from different trees were attained and fumes were formed. Numerous bacteria secluded from different sources were exposed to different stick fumes (dhoop). It was detected that the fumes of Achyranthus aspera controlled the bacterium Streptococcus pyogenes whereas Azadirachta indica, Calotropis gigantica, other components like Ficus benghalensis, Ficus religiosa, Mangifera indica, and Pongamia pinnata were also found to be fruitful in controlling pathogenic bacteria.

The chemical transformation (into vapor or gaseous phase/colloidal forms) of the herbal/plant medicinal preparations in Hawan lead to release of medicinal phytochemicals, which affect many endogenous chemicals (Table 3$)^{8}{ }^{8}$

Table 2: Usual ingredients of 'Hawan Samagri'.

\begin{tabular}{|c|c|c|}
\hline $\begin{array}{l}\text { Vernacular } \\
\text { name }\end{array}$ & Botanical name & Family \\
\hline Jow & Hordeum vulgare & Gramineae \\
\hline Til & Sesamum indicum & Pedalioceae \\
\hline Chauval & Oryza sativa Linn. & Gramineae \\
\hline Makhana & Euryale ferox & Nymphacaceae \\
\hline Kismis & Vitis uinifera & Vitaceae \\
\hline Nariyal & Cocos nucifera & Arecaceae \\
\hline Baadam & Prunus eommunis & Rosaceae \\
\hline Chandan & Santanum album & Santalaceae \\
\hline Deodar & Cedrus deodara & Coniferaceae \\
\hline Agar & Aquilaria agallocha & Thymelaceae \\
\hline Indrayan & Citrullus colocynthis & Cucurbitaceae \\
\hline Jatamansi & $\begin{array}{l}\text { Nardostachys } \\
\text { jatamansi }\end{array}$ & Honeysuckle \\
\hline $\begin{array}{l}\text { Chandni } \\
\text { tagar }\end{array}$ & $\begin{array}{l}\text { Ervatamia } \\
\text { devarricata }\end{array}$ & Apocynaceae \\
\hline Peepal & Ficus religiosa & Moraceae \\
\hline Pista & Pistacia vera & Anacardiaceae \\
\hline Tambul & $\begin{array}{l}\text { Zanthoxylum } \\
\text { armatum }\end{array}$ & Rutaceae \\
\hline $\begin{array}{l}\text { Kapoor } \\
\text { (camphor) }\end{array}$ & $\begin{array}{l}\text { Cinnamomum } \\
\text { camphora }\end{array}$ & Lauraceae \\
\hline $\begin{array}{l}\text { Kesar } \\
\text { (saffron) }\end{array}$ & Crocus sativus L. & Iridaceae \\
\hline Guggul & Commiphora mukul & Burseraceae \\
\hline Ashwagandh & Withania somnifera & Solonaceae \\
\hline Nagarmotha & Cyperus scariosus & Cyperaceae \\
\hline Nagkesar & Mesua Ferrea & \\
\hline Tejapatra & $\begin{array}{l}\text { Cinnamomum } \\
\text { macrocarpum }\end{array}$ & Lauraceae \\
\hline Kulanjan & Alpinia galanga & Zingiberceae \\
\hline $\begin{array}{l}\text { Jaiphal } \\
\text { (Nutmeg) }\end{array}$ & Myristica fragranus & Myristicaceae \\
\hline $\begin{array}{l}\text { Laung } \\
\text { (Clove) }\end{array}$ & $\begin{array}{l}\text { Syzygium } \\
\text { aromaticum }\end{array}$ & Myrtaceae \\
\hline Neem & Azadirachta indica & Meliaceae \\
\hline
\end{tabular}


Table 3: Effects of various active vaporized constituents of Hawan Samagri on human body.

\begin{tabular}{|c|c|c|}
\hline Botanical name & Active component & Effects on human body \\
\hline Saffron Crocus sativus & Crocetin & $\begin{array}{l}\text { Antihypertensive, antitussive, antioxidant, } \\
\text { antidepressant, anticonvulsant }\end{array}$ \\
\hline $\begin{array}{l}\text { Jatamansi Nardostachys } \\
\text { jatamansi }\end{array}$ & Valeranone & $\begin{array}{l}\text { Increase in seizure threshold, Inhibit the } \\
\text { electroshock convulsions }\end{array}$ \\
\hline Coconut Cocos nucifera & $\begin{array}{l}\text { Monounsaturated fatty acids, } \\
\text { Saponins }\end{array}$ & $\begin{array}{l}\text { Inhibit convulsions, increase GABA and, } \\
\text { serotonin level }\end{array}$ \\
\hline Sesame seeds Sesamum indicum & $\begin{array}{l}\text { 1-(5-methyl-2-furanyl)-1- } \\
\text { propanone }\end{array}$ & $\begin{array}{l}\text { Antioxidant, antimicrobial, anti- } \\
\text { inflammatory, anticancer }\end{array}$ \\
\hline Clove Eugenia caryophyllus & Eugenol, $\beta$-caryophyllene. & $\begin{array}{l}\text { Analgesic, antioxidant, anti-inflammatory, } \\
\text { anxiolytic, anticonvulsant. }\end{array}$ \\
\hline Nutmeg Myristica fragrans & Myristicin and macelignan & Reduce severity of seizures. \\
\hline Nagkesar Mesua ferra & Sesquiterpene & Anti-inflammatory, anti-pyretic. \\
\hline Tagar Valeriana wallichi & Valerian & Antispasmodic, sedative, anticonvulsant. \\
\hline Agar Aquilana malaccensis & Sesquiterpenes & Sedative action. \\
\hline Nagarmotha Cyperus rotundus & Cyperone & $\begin{array}{l}\text { Anti-inflammatory, anti-microbial, anti- } \\
\text { fungal, anticonvulsant action. }\end{array}$ \\
\hline Ber Zizphus jujube & $\begin{array}{l}\text { Flavonoids, saponins, tannins, } \\
\text { vitamin A, vitamin B }\end{array}$ & $\begin{array}{l}\text { Anti-microbial, anti-ulcer, antispasmodic, } \\
\text { immunostimulant, anticonvulsant action. }\end{array}$ \\
\hline Phoolmakhane Nelumbo nucifera & N-nornuciferine & Anticonvulsant action. \\
\hline Mango Mangifera indica & PGG, polyphenolics, flavonoids & $\begin{array}{l}\text { Increase GABA levels, anticonvulsant } \\
\text { action. }\end{array}$ \\
\hline Neem Azadirachta indica & Azadirachtin & $\begin{array}{l}\text { Antibacterial, antiviral, immune booster, } \\
\text { anti-inflammatory }\end{array}$ \\
\hline Sandal-wood Santalum album & Tricyclic $\alpha$-santalol. $\beta$-Santalol & $\begin{array}{l}\text { Anti-inflammatory, anti-bacterial, } \\
\text { fungistatic. }\end{array}$ \\
\hline
\end{tabular}

\section{DISCUSSION}

Yagya as well as regular chanting of Mantra's helps counter many ailments as well as environmental hazards as mentioned below.

\section{Air pollution}

Air pollution has both serious acute and chronic effects on human health. Yagya is steered with selected medicinal preparation of herbs that is forfeited in the holy fire along with the chanting of specific vedic hymes (mantras).

The fumes lead to purification of air by oxidizing the carbonic compounds and along with that they have antimicrobial properties which benefit the people around. They have disguising effect on various pollutants in the atmosphere including the oxides of sulphur. ${ }^{4}$ Surplus Carbon dioxide in the atmosphere is also reduced to formaldehyde which acts as a powerful antiseptic with germicidal action. The joint chanting of mantra that adapt rhythm in front of Yagya, enlarges the mantra Shakti exponentially and expands the mantra vibrations to all dimensions, which have unlimited radiant effect in the outer space. ${ }^{9}$

\section{Antifungal effect}

Laboratory tests were directed by exposing petriplates having czapek dox agar medium, in a closed room, before and after fumigating 'Hawan samagree' and plant parts (dried leaves, bark, sawdust) of Mangifera indica, Azadirachta indica and Santanum album. Results displayed substantial decrease in concentration of fungal load. This method can be successfully applied at actual work places like small flour mills, ginneries, cobbler shops etc., to limit the concentration of lethal fungi like Aspergillus, Penicillium, Alternaria, Curvularia, Cladosporium etc. ${ }^{10}$

\section{Antiepileptic effect}

The healing value of Hawan is grounded on the ingredients used. Ghee when burnt like oil will produce natural fumes that heal the respiratory system and clear any blood clots and bacterium affecting the nasal, lungs and veins. The direct neuro-pharmacological properties of essential oils, aroma of the oil may apply a pleasant response via the olfactory system in turn, changing the hypothalamic control of hormones and neurotransmitters. ${ }^{8}$ The medium chain fatty acids in pure Ghee get changed into ketones and provide the epilepsy patient brain with the energy it needs to endure as well as 
brain healing and repair. Small amounts of $\mathrm{CO}_{2}$ inhaled by the persons performing Yagna acts as a stimulant with which aromatic fumes are inhaled which aid in curing mental disorders. ${ }^{11}$ Saffron used in Hawan, elevates seizure threshold and block Pentylenetetrazole induced (PTZ) convulsions can be ascribed to its modulatory effect on GABA neurotransmission. The possible mechanism of anti-epileptic activity has been shown to be by growing the GABAergic neurotransmission. Jatamansi is a popular Ayurvedic herb and used in numerous formulations. It has been used in the treatment of many diseases and has some activities including anticonvulsant activity, anti-parkinson's activity, tranquillizing activity, hepatoprotective, neuroprotective etc. ${ }^{12}$ Nutmeg (Myristica fragrans) has anticonvulsant activity against PTZ and lithium-pilocarpine induced seizures and lesser doses were more effective in inhibiting seizures. Clove is also a significant part of Havan Samagri. Clove essential oil has been shown to meaningfully increase the onset of convulsion and decrease its duration in dose dependent manner compared to the control for strychnine and picrotoxin-induced convulsion. ${ }^{13}$

\section{Nosocomial infections}

Camphor purifies the air in the diffusive atmosphere and achieves various medicinal benefits when we inhale. It acts as a germ killer, mosquito and fly repellent and bounds spreading of the virus in that place. The chief ingredient in Hawan is mango wood (Mangifera indica) which when burnt releases formaldehyde a gas which slays harmful bacteria thus purifying the atmosphere. The jaggery burnt in the Hawan also releases the formaldehyde gas. ${ }^{14}$

Medicinal smoke significantly removes human pathogenic bacteria Corynebacterium urealyticum causing urinary tract infection, Kocuria rosea causing catheter-related bacteremia, Staphylococcus lentus causing splenic abscess, Staphylococcus xylosus causing acute pyelonephritis, Tsukamurella inchonensis causing acute myelogenous leukemia, Enterobacter aerogenes causing nosocomial infections, Sphingobacterium spiritivorum causing extrinsic allergic alveolitis and Sphingomonas sanguinis producing nosocomial non-life threatening infections. ${ }^{15}$

\section{Other health benefits}

Medicinal-smoke intake can deliver benefits in curing ailments such as- headache, disease related to sensory organs, migraine, hiccups, asthma, goiter, fungal infection, jaundice, cold, sneezing, insomnia, hair fall etc. The inhalation of medicinal-smoke of a specific herbalpowder combination of neem leaves, bach, kooth, harad, saraso and googal ends high fever in patients. Inhalation of the medicinal-smoke of a specific herbal-powder combination made using neem leaves, bach, hing, sendha namak, saraso was seen to destroy worms and pus. ${ }^{1}$ The mind used in Yagna obtains deep effect of harmonizing from incantatory spiritual verse known as "mantra." This ancient Indian spiritual science of sound vibrations had been utilised to help the mind, body and life. According to a study, about $60 \%$ of patients displayed improvement with respect to digestion, hypertension, mental agitation and sleep after chanting Mantra's.

\section{CONCLUSION}

Vedic literature defines treatment of extensive range of diseases (both infectious and non-infectious) and ailments through Yagya, along with the precautions, detailed procedures, causes of diseases, therapeutic supplements etc.

\section{Funding: No funding sources \\ Conflict of interest: None declared \\ Ethical approval: Not required}

\section{REFERENCES}

1. Verma S. Yagya therapy in vedic and ayurvedic literature: a preliminary exploration. Interdisciplinary J Yagya Res. 2018;1(1):15-20.

2. Brahmavarchas. Yagyachikitsa-yagyopathy: ek samagra evam divya chikitsa paddhati (Hindi). In: Yagya Chikitsa. Shri Vedmata Gayatri Trust, Shantikunj, Haridwar (Uttarakhand). India. 2010;1535.

3. Raghuvanshi M, Pandya P, Joshi RR. Yagyopathic herbal treatment of pulmonary tuberculosis symptoms: a clinical trial. Altern Complement Ther. 2004;10(2):101-5.

4. Singh R. Yagya vedic way to prevent air pollution Dev Sanskriti. Interdisciplinary Int J. 2012;1:29-35.

5. Limaye VG. Agnihotra (the everyday homa) and production of brassinosteroids: a scientific validation. IJMER. 2018;8(12):41-51.

6. Nautiyal CS, Chauhan PS, Nene YL. Medicinal smoke reduces airborne bacteria. J Ethnopharmacol. 2007;114(3):446-51.

7. Prabhu N, Rengaramanujam J, Joice AP. Efficacy of plants-based holy stick fumigation against infectious bacteria. Indian J Traditional Knowl. 2009;8(2):27880 .

8. Bansal P. Is there any scientific basis of hawan to be used in epilepsy-prevention/cure? J Epilepsy Res. 2015;5(2):33-45.

9. Pandya P. Applied science of ygaya for health and environment. Haridwar. Shri Vedmate Gayatri Trust. 2009.

10. Tewary R. Hawan: an effective method to reduce fungal load at small work places. Aerobiologia. 1997;13:135-8.

11. Ghadrdoost B, Vafaei AA. Protective effects of saffron extract and its active constituent crocin against oxidative stress and spatial learning and memory deficits induced by chronic stress in rats. Eur J Pharmacol. 2011;667:222-9. 
12. Abe K, Saito H. Effects of saffron extract and its constituent crocin on learning behavior and longterm potentiation. Phytother Res. 2000;14:149-52.

13. Vida JA, Foye WO, Lemke TL, Williams DA. Principles of medicinal chemistry. Williams and Wilkins, Wolters Kluwer, London. 1995: 163-179.

14. Mayoral NT, Bellido JL, Rodríguez JA. Incidence and characteristics of urinary tract infections caused by Corynebacterium urealyticum (Corynebacterium group D2). Eur J Clin Microbiol Infect Dis. 1994;13:600-4.
15. Samanth TU, Jha SG, Sinha V, Patel S, Desai KJ. Effect of smoke from medicinal herbs on the nosocomial infections in ENT outpatient department. Indian J Otol. 2018;24:9-12.

Cite this article as: Chaube RK, Chaube VK, Saxena P, Solanki K, Tiwari RVC, Tiwari H. Scientific rationale of Yagya: a review. Int J Community Med Public Health 2020;7:2831-5. 